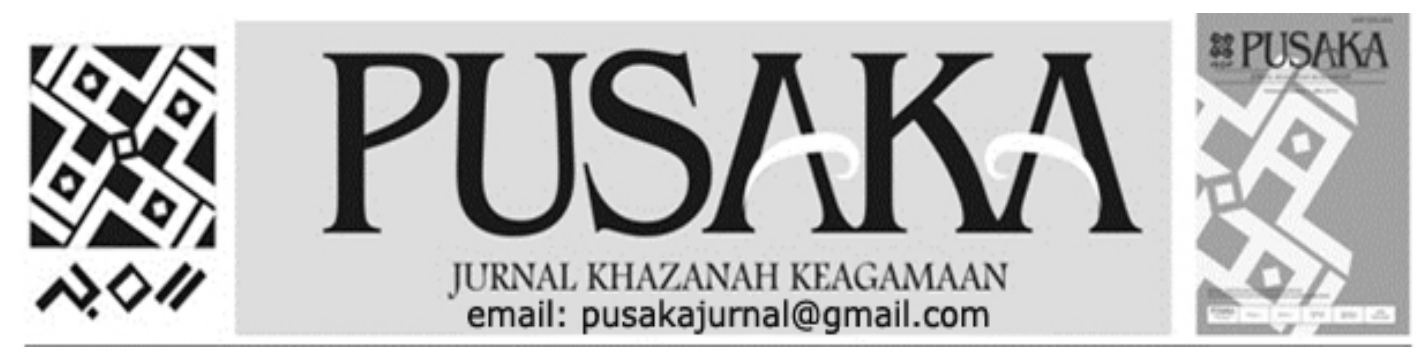

Pesona Kurikulum SMP Islam Terpadu ‘Al-Qalam' Kota Kendari

\author{
The Attractiveness of Curriculum Integrated Islamic Middle School 'Al-Qalam' \\ Kendari City
}

\title{
Baso Marannu
}

Balai Penelitian dan Pengembangan Agama Makassar

J1.A.P.Pettarani No.72 Makassar. Telp:0411-452952

Email: athobasomarannu70@gmail.com

\begin{tabular}{|c|c|}
\hline $\begin{array}{c}\text { Info } \\
\text { Artikel }\end{array}$ & Abstract \\
\hline $\begin{array}{c}\text { Diterima } \\
7 \\
\text { Juni } \\
2017 \\
\text { Revisi I } \\
3 \\
\text { Agustus } \\
2017\end{array}$ & $\begin{array}{l}\text { Tulisan ini adalah hasil penelitian kualitatif dengan berfokus pada Sekolah } \\
\text { Menengah Pertama Islam Terpadu Al-Qalam Kota Kendari, khususnya } \\
\text { pengembangan Kurikulum kekhasan bidang Pendidikan Agama Islam baik dalam } \\
\text { pembelajaran sebagai kurikulum inti dan kurikulum lokal. Hasil penelitian ini } \\
\text { menyimpulkan bahwa Landasan, komponen dan Prinsip pengembangan kurikulum } \\
\text { Pendidikan Agama dan keagamaan di SMP IT Al-Qalam Kendari dikembangkan } \\
\text { dari inovasi dan kreatifitas pengelola sekolah secara mandiri yang diajarkan pada } \\
\text { peserta didik baik secara monolitik maupun holistik (integratif) yang disusun oleh } \\
\text { Pendidik dan Tenaga Kependidikan di SMP-IT Al-Qalam' Kota Kendari dan atau } \\
\text { mengadopsi dari kurikulum yang disepakati oleh sekolah-sekolah Islam Terpadu di } \\
\text { Indonesia yang terhimpun dalam Jaringan Sekolah Islam Terpadu (JSIT) di } \\
\text { Indonesia. Kapasitas Pendidik yang mengajarkan pendidikan agama dan } \\
\text { keagamaan baik secara monolitik maupun integratif sudah baik namun } \\
\text { kapabilitasnya masih perlu dikembangkan. Rekomendasi dari penelitian ini } \\
\text { diantaranya perlunya pemerintah terutama Kementerian Agama untuk mengkaji } \\
\text { secara mendalam pola pengembangan kurikulum pendidikan agama dan } \\
\text { keagamaan yang diterapkan di SMP IT secara umum terutama nilai budaya yang } \\
\text { berkearifan lokal dan rasa nasionalisme, sesuai dengan tingkatan psikologi } \\
\text { perkembangan anak dan tujuan pendidikan secara nasional, termasuk memberikan } \\
\text { pelatihan bagi pengelola SMP IT untuk meningkatkan Kapabilitasnya } \\
\text { Kata Kunci: Pendidikan Agama, Kurikulum, Sekolah Islam Terpadu }\end{array}$ \\
\hline $\begin{array}{c}\text { Revisi II } \\
27 \\
\text { September } \\
2017\end{array}$ & $\begin{array}{l}\text { This paper is the result of qualitative research by focusing on Al-Qalam Integrated } \\
\text { Islamic High School of Kendari City, especially curriculum development of } \\
\text { uniqueness in the field of Islamic Religious Education both in learning as the core } \\
\text { curriculum and local curriculum. The results of this study concluded that the } \\
\text { Platform, Components and Principles of curriculum development of Religious } \\
\text { Education and religious SMP IT Al-Qalam Kendari developed from the innovation } \\
\text { and creativity of school administrators independently taught to the learners either } \\
\text { monolithic or holistic (integrative) prepared by educators and personnel in the } \\
\text { Junior-IT 'Al-Qalam' Kendari and or adopt the curriculum agreed by Integrated } \\
\text { Islamic schools in Indonesia who gathered in Integrated Islamic school Network } \\
\text { (JSTT in Indonesia. Capacity Educators who teach religion and religious } \\
\text { education both monolithic and integrative capabilities already good but still needs } \\
\text { to be developed. Recommendations from the study include the need for the } \\
\text { government, especially the Ministry of Religious Affairs to examine in depth the } \\
\text { development pattern curriculum religious education and religious were applied in } \\
\text { SMP IT in general, especially the cultural value berkearifan local and sense of } \\
\text { nationalism, in accordance with the level of psychological development of children } \\
\text { and educational purposes nationwide, including providing training for SMP IT } \\
\text { managers to improve their capabilities. } \\
\text { Keywords: Religious Education, Curriculum, Integrated Islamic School }\end{array}$ \\
\hline
\end{tabular}




\section{PENDAHULUAN}

Menarik apa

yang

dikemukakan oleh Tilaar (2006:12)

beliau mengungkapkan bahwa dunia pendidikan telah berubah, harus sesuai dengan standar kompetensi, inilah yang diistilahkan oleh Tilaar sebagai epistema ekonomi menguasai pemikiran pendidikan.

Geliat lembaga pendidikan bergerak cepat dengan berbagai keunggulannya, mulai aspek kualitas manajemen sekolah, proses pembelajaran, metode, strategi terus mengalami pembaharuan yang inovatif dan kreatif.

Penyelenggaraan pendidikan dasar dan menengah yang menarik saat ini adalah pendidikan swasta di bawah naungan Kementerian Pendidikan Nasional, namun konsep kurikulum dan sistem pembelajarannya mengedepankan nilai-nilai Ajaran Islam yang kita kenal dengan Sekolah Islam Terpadu (SIT), jika SIT sebagai lembaga pendidikan yang mengutamakan nilai-nilai Islam pada semua mata pelajaran bukan saja Pendidikan Agama Islam secara umum, mengapa sekolah yang dikelola oleh swasta dan hampir berkembang di seluruh Indonesia tersebut tidak berdiri sebagai Madrasah saja, yang memang telah diatur oleh pemerintah sebagai sekolah umum yang bercirikan Islam.

SIT mulai marak diperkenalkan di era tahun 1990-an, sejak itu lembaga pendidikan tersebut terus meningkat jumlahnya sampai sekarang walaupun fenomena perkembangan SIT ini cenderung hadir di perkotaan, beberapa SIT yang ada di Indonesia bahkan sudah membentuk suatu wadah atau lembaga perkumpulan yang dikenal dengan nama Jaringan Sekolah Islam Terpadu (JSIT).

Keberhasilan sekolah Islam Terpadu mengembangkan standar pendidikan ke-khasan 'Terpadu' termasuk pengembangan kurikulum 'Islam' membuat daya tarik serta kepercayaan masyarakat seolah memberikan 'pesona' (daya tarik) kurikulum yang ditawarkannya, pendidikan moral peserta didik menjadi 'trade mark' SIT di mata masyarakat.

Pada aspek pengembangan kurikulum, sekolah Islam terpadu memberikan porsi yang lebih pada pembelajaran tambahan (hidden curriculum) yang berhubungan dengan pendidikan agama seperti hafalan beberapa juz dalam Alquran.

Olehnya penelitian pendidikan SIT pada aspek kurikulum perlu dilakukan dengan tujuan dapat memberikan alternatif penilaian dalam meningkatkan mutu pendidikan Islam pada sekolah yang berlabel 'Terpadu', sehingga ke depan pemerintah dan pemerhati dunia pendidikan dapat menerapkan model kurikulum yang tepat yang digunakan oleh lembaga pendidikan, terutama pendidikan yang mengedepankan nilai keagamaan.

Secara umum konsep SIT ini juga sama dengan pendidikan madrasah perbedaannya hanya persoalan "kemasan", disatu sisi ada stigma masyarakat memandang bahwa madrasah lembaga pendidikan agama yang 'tradisional' sementara di sisi lain SIT untuk kalangan tertentu mengidentikkan dengan lembaga pendidikan Islam 'modern'. Walaupun persoalan tersebut masih perlu pengkajian lebih lanjut. 
Hampir sebagian besar SIT yang hadir di perkotaan, animo orang tua untuk menyekolahkan anak mereka di SIT, bagaimana sistem 'kemasan kurikulum' yang mereka ramu sedemikian rupa, sehingga menjadi 'pesona' (daya tarik) masyarakat perkotaan.

Ketika sebuah lembaga pendidikan menggunakan label 'Islam Terpadu' tentu perlu pendalaman lebih lanjut, bagaimana konsep 'KETERPADUAN' kurikulum yang maksudkan oleh pengelola SIT, apakah keterpaduan kurikulum pendidikan Islam yang mereka gunakan, atau keterpaduan manajemen sekolah umum dengan sekolah Islam, atau sistem pembelajaran yang 'terpadu' dengan konsep umum dan konsep Islam, inipun suatu yang menarik disasar lebih lanjut.

Menilik gambaran fenomena di atas, maka penelitian tentang sekolah Islam terpadu ini diharapkan memberikan gambaran yang jelas dan konkrit mengenai penyelenggaraan pendidikan di Sekolah Islam Terpadu secara utuh dan konfrehensif terutama manajemen kurikulum dan sumber daya yang mengawal karakter kurikulum yang ditawarkan oleh pengelola SIT, terkhusus fokus pada SMPIT di Kendari.

Dari latar belakang tersebut di atas dapat dirumuskan pokok masalah yaitu bagaimana Pengembangan Kurikulum Pendidikan Agama Islam (PAI) sebagai Kekhasan Sekolah Menengah Pertama Islam Terpadu Al-Qalam Kota Kendari?

Tujuan penelitian secara umum mengetahui tentang pola strategi dan implementasi pengembangan kurikulum yang berkarakteristik kekhasan Sekolah Islam Terpadu di Indonesia, terutama di SMP IT 'AlQalam' Kota kendari,

\section{Kajian Teori \\ Pengertian Sekolah Islam Terpadu}

Pembelajaran terpadu merupakan suatu pendekatan yang berorientasi pada praktek pembelajaran yang disesuaikan dengan kebutuhan perkembangan anak. (Suprapto, dalam jurnal Edukasi Vol.12, 2014:19). Buku Standar Mutu Kekhasan Sekolah Islam terpadu yang diterbitkan oleh Jaringan Sekolah Islam Terpadu Indonesia (2014:5) SIT pada hakekatnya adalah sekolah yang mengimplementasikan konsep pendidikan Islam berlandaskan Al Quran dan As Sunnah. Maksudnya adalah Islam yang utuh.

\section{Kajian Riset Sebelumnya}

Hasil penelitian Suyatno dalam jurnal Analisa bahwa preferensi orang tua terhadap SDIT meliputi faktor teologis, sosiologis, dan akademis. Posisi guru sebagai seorang murabby (pemandu moral) menjadi daya dukung utama sekolah ini. (Suyatno, 2015:121-133). Penelitian yang dilakuan oleh Robingatin menyimpulkan bahwa Implementasi JSIT, SMPIT Daarussalam Sangatta Utara dilakukan dengan dua cara yakni : Pertama, memasukan nilai-nilai ajaran Islam melalui pembalajaran secara formal, Kedua, Kegiatan pembelajaran melalui ProgramProgram Sekolah dan Muatan Lokal (MULOK). (Robingatin, 2015: 127154) 
Hasil Penelitian Latief, sumber rekrutmen tenaga pendidik SMPIT Al Azhar Jambi cenderung menggunakan sumber eksternal yang terfokus pada rekrutmen eksternal bersifat referensi. (Latief, 2011: 195207). Penelitian Abidin, menyimpulkan SDIT di Surakarta mengarahkan semua kegiatannya, pada visi misi masing-masing sekolah yang variative dan belum terpadu secara ideal tetapi masih bersifat kurikulum pendekatan "mata pelajaran" (Abidin: 166-179)

Penelitian

Arifin, menyimpulkan bahwa Kemunculan sekolah elite muslim merupakan salah satu refleksi atas kelangkaan ulama, pemimpin dan ilmuan, bahkan menjamurnya lembagalembaga tersebut sedikit demi sedikit mulai mengacu kepada praktekpraktek ekonomi, yang identik dengan komersial dan marginalitas (Arifin, 2014: 177-200). Penelitian Supar menyimpulkan bahwa SDIT mempunyai produk baru yang harus ditawarkan pada masyarakat SDIT Nurul Fikri Tulungagung sangat diminati masyarakat. (Supar, 2014: 158-170)

Penelitian Apriani tentang Peran Kepala Sekolah SDIT Nurul Hadi Samarinda yaitu mengenai sarana dan prasarana dan sumberdaya manusia yang masing kurang, sehingga menimbulkan terhambatnya proses pelaksanaan pembelajaran (Apriani, 2015: 564577). Hasil penelitian Soemanto (Edukasi, Vol.12, 2014) tentang pendidikan agama Islam Terpadu pada SMPIT Bina Umat Yogyakarta menyimpulkan bahwa minat masyarakat terhadap sekolah Islam terpadu terus meningkat.

\section{Pengertian dan Dasar \\ Pengembangan Kurikulum}

Istilah 'kurikulum' memiliki beberapa tafsiran oleh pakar-pakar dalam bidang pengembangan kurikulum dari dulu hingga saat ini. Kurikulum berasal dari kata 'Curriculae' artinya jarak yang harus ditempuh oleh seorang pelari, namun secara spesifik kurikulum dilihat dari segi pertama isi dan materi pelajaran yang berarti sejumlah mata ajaran yang harus ditempuh dan dipelajari oleh peserta didik untuk memperoleh sejumlah pengetahuan, (Hamalik, 2013:16-18). Menurut Sukmadinata dalam Rahman (2012:2).

Pandangan lain tentang kurikulum adalah merupakan program pendidikan yang disediakan oleh lembaga pendidikan (sekolah) bagi peserta didik. (Majid, 2014:1). Menurut Ahmadi dkk (2012:110) mengutip pendapat willoim B.Ragan (1963), Beauchmap (1964) dan Harorl B. (1965) mendefenisikan kurikulum menekankan pada aspek pengalaman dan kegiatan belajar siswa, jadi yang mereka sebut kurikulum adalah semua pengalaman dan kegiatan belajar yang direncanakan oleh guru (sekolah) dan dialami siswa.

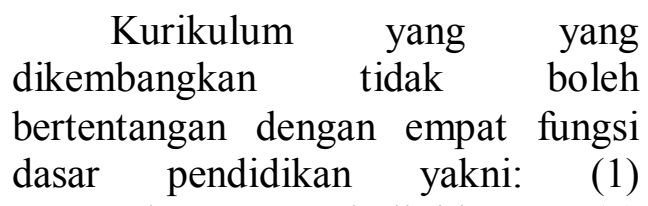

Pengembangan individu;

Pengembangan cara berfikir dan teknik penyelidikan; (3) Pemindahan warisan budaya; (4) Pemenuhan kebutuhan sosial yang vital. (Rohita, 2010: 22-23).

Untuk mendapatkan kurikulum yang bermakna, kurikulum harus dikembangkan dengan 
memperhatikan

(1) Prinsip

Relevansi; (2) Efisiensi dan Efektifitas; (3) Fleksibilitas (Ahmadi, dkk, 2012:113-116).

\section{Manajemen Sekolah Islam Terpadu}

Manajemen sebagai suatu proses merupakan pendekatan perilaku administratif, dimana secara umum terbagi menjadi lima bagian yaitu planning, organizing, commanding, coordinating, dan controling, (Rohiat, 2010: 18-19)

Koont O. Donnel dalam Sagala (2007:55) mengemukakan bahwa manajemen adalah proses merencanakan dan mempertahankan lingkungan agar individu dapat bekerjasama dalam kelompok, secara efesien dalam rangka mencapai tujuan, agar manajemen perhatian terhadap produktivitas dan etos kerja yang tinggi berimplikasi efektivitas dan efesiensi.

Ditambahkan Sagala (2007:54) bahwa manajemen sekolah diartikan sebagai proses pendayagunaan sumber daya sekolah melalui kegiatan fungsi-fungsi perencanaan, pengorganisasian, penggerakan, dan pengendalian secara lebih efektif dan efesien.

Beberapa hasil penelitian yang telah digambarkan sebelumnya di atas memberikan penjelasan tentang kekhasan dari sekolah Islam terpadu baik pada aspek kurikulum maupun sistem pembelajarannya. Dan juga memberikan gambaran tentang meningkatnya minat masyarakat terhadap konsep dari sekolah Islam terpadu.

\section{Prinsip Penyelenggaraan SIT}

Secara umum prinsip penyelenggaraan pendidikan pada Sekolah Islam terpadu sama saja dengan sekolah-sekolah pada umumnya di Indonesia, yang membedakan hanyalah reformulasi kurikulum yang berlaku secara nasional dengan memadukannya dengan nilai-nilai agama dan keagamaan Islam.

Hal tersebut juga telah dimuat dalam buku Standar Mutu Jaringan Sekolah Islam terpadu (JSIT) Indonesia 2014:6-7: (1) Menyakini bahwa pendidikan Iskam merupakan aktivitas dakwah; (2) Pendidikan dilaksanakan dengan tulus ikhlas, dedikasi yang tinggi dan cara-cara yang bijak dan dipandang sebagai kewajiban menjalankan perintah Allah Swt. (QS, 16:125). Menjalankan aktivitas pendidik merupakan amanah yang diterima dari orang tua siswa, dan menunaikan amanah merupakan perintah Allah Swt. (QS. An Nisa: 58); (3) Pendidikan hakikatnya mengajarkan kandungan Islam (Alquran dan Hadits) sebagai satu kesatuan 'Ilmu Allah'. SIT berupaya mengintegrasikan Ilmu Allah yang tersurat dalam Alquran dan Hadits ('Ulumul Qauliyah) dengan nilai kauniyah dan qauliyah dalam bangunan kurikulum.

\section{Misi dan Tujuan Pendidikan SIT}

Sekolah Islam Terpadu sebagaimana yang termuat dalam Buku Standar Mutu JSIT Indonesia 2014:7 menegaskan misi pendidikannya, yaitu:

Menuntaskan sasaran pembelajaran yang dicanangkan pemerintah dalam konteks kurikulum nasional; (2) 
Mengajarkan kemampuan membaca Alquran dengan standar tahsin dan tartil (membaca sesuai aturan hukum tajwid), dan kemampuan menghafal Alquran (tahfizhul Qur'an) dengan standar minimal dan juz setiap tingkat satuan pendidikan; (3) Memperkuat pembelajaran agama Islam, dengan memperkaya konten kurikulum yang mengarah kepada pemahaman dasar akan ajaran Islam dan pembinaan fikrah, muaqif, dan suluk Islamiyah; (4) Membina karakter/muwashofat kepada peserta didik secara bertahap menuju terbentuknya generasi pemimpin yang cerdas dan taqwa.

Ada sepuluh Tujuan Pendidikan SIT adalah membentuk karakter utama kepada seluruh peserta didik termasuk pendidik dan tenaga kependidikan di SIT dan wajib diterpakan bagi sekolah yang terhimpun dalam JSIT. Sebagaimana dijelaskan dalam Buku Standar Mutu JSIT Indonesia 2014:7-8 ada sepuluh tujuan pendidikan SIT yaitu: (1) Salimul Aqidah; (2) Sohihul Ibadah; (3) Matinul Khuluq; (4) Qodirun 'alal Kasbi; (5) Mutsaqoful Fikri; (6) Qowiyul jismi; (7) Mujahadah li nafsihi; (8) Munazhom fi Syu'nihi; (9) Harisun 'alal waqti;

(1) Nafi'un li Ghohiri.

\section{a) Strategi pelaksanaan SIT}

Strategi dan pendekatan yang diterapkan dalam menjalankan misi dan upaya mencapai tujuan pendidikan, dan diharapkan dapat mendukung keefektifan penyelenggaraan sekolah yang tergabung dalam Jaringan Sekolah Islam terpadu secara nasional.

Strategi tersebut secara jelas diatur dalam Buku Standar Mutu JSIT Indonesia 2014:9 sebagai berikut: (1) Mewujudkan lingkungan sekolah yang kondusif (biah soliha); (2) Menerapkan aturan dan norma yang bersendikan nilai-nilai Islam dalam berbagai hal; (3) Menerapkan pembelajaran yang efektif; (4) Mengembangkan pembelajaran yang berpusat pada peserta didik; (4) Melakukan proses islamisasi dalam proses pembelajaran;

Memperkuat program pembinaan kesiswaan dengan kurikulum pendamping (ko-kurikuler) dan kurikulum tambahan (ekstrakurikuler); (6) Menjalin kemitraan yang efektif dengan berbagai pihak yang terkait; (7) Menyelenggarakan sekolah penuh waktu fullday school; Memastikan kepala sekolah dan guru memiliki visi, misi, semangat dan pemikiran (ghiroh dan fikroh) serta sikap dan perilaku yang sejalan dengan falsafah, nilai, visi, dan misi pendirian SIT; (1) Memberlakukan tata tertib, norma dan etika yang dibuat bersandar kepada etika dan nilai Islami (akhlak mulia) dan kepatutan sosial.

\section{b) Standar Pendidikan SIT}

Standar pendidikan yang dikembangkan pada sekolah Islam terpadu selain mengacu pada standar nasional pendidikan melalui Peraturan Pemerintah Nomor 19 Tahun 2005 dan beberapa Peraturan Menteri lainnya, juga mengembangkan standar pendidikan berdasarkan kekhasan sekolah Islam terpadu, sebagai berikut; Standar Pendidik dan Tenaga Kependidikan, Standar Sarana dan Prasana, Standar Pembiayaan, Standar Kurikulum, Standar Pengelolaan, Standar Kerjasama, Standar Proses, Standar Penilaian, Standar Pembinaan 
Peserta Didik, Standar Pendidikan Agama Islam, Standar Kompetensi Lulusan, dan Standar Mutu PAUDIT. (Buku Standar Mutu JSIT Indonesia 2014:15-289)

\section{Metode Penelitian}

Penelitian mengenai pengelolaan Sekolah Islam Terpadu. Dengan mengambil fokus data pada Sekolah Menengah Pertama Islam Terpadu (SMP IT) Al-Qalam, yang terletak di Jl. Asrama Haji no. 8, Kelurahan Wundudopi, Kecamatan Baruga Kota Kendari.

Penelitian ini adalah penelitian kualitatif dengan pendekatan studi kasus menempatkan peneliti sebagai instrument utama. Penelitian ini akan mengeksplorasi secara mendalam pola pengembangan kurikulum yang dijadikan kekhasan Sekolah Islam Terpadu, termasuk mendalami kapasitas dan kapabilitas sumbner daya yang dimiliki oleh SMP IT Al Qalam Kota Kendari.

\section{Hasil dan Pembahasan Profil SMP IT 'Al-Qalam Kota Kendari}

Penelitian tentang sekolah Islam Terpadu yang fokus pada satuan pendidikan SMP di Kota Kendari, yang dijadikan sumber data adalah SMPIT Al Qalam, yang terletak di Kecamatan Baruga Kelurahan Wundulopi, menurut data statistik (2015) persebaran penduduk di Kota Kendari terpusat di Kecamatan Baruga, berkisar 57.421 jiwa.

Sekolah-Sekolah yang berlabel 'Islam Terpadu' bukan saja karena peminatnya yang besar tapi biaya pendidikan yang dipatok oleh pengelolanya tergolong tinggi mulai dari biaya awal sekolah dan biaya bulanan yang harus dibayarkan orang tua peserta didik, persoalan biaya penyelenggaraan pendidikan yang sebagian besar menargetkan keluarga muslim yang memiliki tingkat ekonomi menengah ke atas walaupun tidak semua namun itulah kenyataan yang ditemukan di lapangan, hal ini tentu menarik untuk ditelusuri lebih mendalam, bukan saja pada label 'Islam' tapi kemasan kurikulum sebagai core education namun konsep 'Keterpaduan'nya dengan mengintegrasikan pendidikan agama dan keagamaan pada semua mata pelajaran juga menjadi marketable yang menarik perhatian orang tua.

Pendirian sekolah Islam Terpadu Di Kota Kendari sendiri, terbilang masih sedikit, terutama pada satuan pendidikan setingkat SMP hanya ada satu sekolah yakni SMPIT Al Qalam, yang banyak justru pada tingkatan Sekolah Dasar (SD), dan Taman Kanak kanan Islam Terpadu (TKIT) namun pada beberapa provinsi di Indonesia terutama di Pulau Jawa beberapa sekolah berlabel Islam Terpadu berkembang cukup pesat. Tren ini nampaknya juga terus berkembang dan menjalar di luar pulau jawa, termasuk di Kota Kendari.

SMPIT Al Qalam Kota Kendari berdiri pada tahun 2014, dibawah naungan Yayasan Amal Sholeh Kendari, letaknya di jalan Asrama Haji no.8, tepatnya di Kecamatan Baruga kelurahan Wundudopi. SMPIT Al-Qalam didirikan tahun 2014 menempati lahan $1.110 \mathrm{~m} 2$, saat ini membina 60 siswa, dengan tenaga pengajar 12 guru (hanya 1 guru tetap dan yayasan) 10 orang guru tidak tetap 
Pada sisi pinggir gedung nampak tanaman segar menghiasi taman sekolah, termasuk beberapa baruga tempat istirahat peserta didik. Kompleks TKIT, SDIT, dan SMPIT 'Al-Qalam menyatu dalam satu lingkungan sekolah, pada bagian terdepan terdapat Gedung Mini Market dan Mushollah sekolah, sisi kanan TKIT dan Pada bagian tengah SDIT sedangkan SMP IT terletak bagian pada bagian belakang Komplek Yayasan Amal Soleh sebagai induk sekolah 'Al-Qalam'.

Pada ruang kelas pembelajaran kursi yang digunakan adalah kursi kayu berwarna coklat, masingmasing siswa duduk pada kursi dan meja tunggal, siswa laki-laki dipisahkan dengan siswa perempuan, jumlah seluruh siswanya 60 orang, sedangkan jumlah tenaga pendidikan 16 orang, di SMP IT Al-Qalam guru laki-laki akrab dipanggil Ustadz, sedangkan yang perempuan dipanggil ustadzah.

SMP IT Al-Qalam menggunakan sistem pendidikan full day, pembelajaran dimulai pada pukul 07.15 hingga pukul 16.00 sore hari setelah sholat Ashar, siswa baru diperkenankan meninggalkan sekolah. Pembelajaran hanya lima hari kerja, yakni hari senin hingga jumat, pada hari sabtu dan minggu mereka libur sekolah.

Tenaga pendidik di SMP IT 'AlQalam' rata-rata masih muda, namun tuntutan kualitas akademik dan pendidikan agama dan keagamaan calon pendidik menjadi prioritas utama, jika ingin mendaftar sebagai pendidik di SMP IT 'Al-Qalam' karena itu guru-guru yang dilibatkan sebagai pengajar di sekolah tersebut tidak sembarangan, setiap pengajar yang ingin mendaftar di SMP IT 'AlQalam' dilakukan seleksi secara ketat, terutama mereka yang memahami ilmu agama Islam yang baik.

Penerimaan guru dilakukan secara terbuka, baik dari mulut ke mulut juga melalui teknologi termasuk mengoptimalkan media social, namun lebih banyak yang mendaftar karena referensi, artinya calon pendidik yang ingin mengajar di sekolah ini sebagian besar organisasi yang diikuti saat mahasiswa adalah dari organisasi Ekstra Kampus yaitu MPM (mahasiswa Pencinta Mushollah) termasuk dari organisasi KAMMI (Kesatuan Aksi Mahasiswa Muslim Indonesia), ungkap ibu Nurafiah sebagai kepala sekolah sekaligus menjabat Koordinator JSIT di Kota Kendari.

Yayasan Amal Soleh sebagai induk dan pemilik dari SMP IT 'AlQalam' didirikan oleh beberapa orang makanya disebut dengan Yayasan Amal Soleh, awalnya yayasan ini bergerak dalam bidang dakwah, pertukaran dai, setelah itu mendirikan lembaga pendidikan, awalnya mendirikan TKIT, kemudian SDIT dan terakhir pada tahun 2014 mendirikan SMP IT 'AlQalam', tutur pak Jumadi Wakil Ketua Yayasan.

Penentuan guru, staf hingga kepala sekolah hampir sebagian besar ditentukan oleh pihak yayasan. Kebijakan yayasan lebih bersifat kebijakan umum terutama kepentingan untuk semua satuan pendidikan yang dinaungi. Yang menggaji seluruh guru dan staf adalah yayasan, makanya besaran gaji yang diberikan tergantung 
kesanggupan yayasan amal soleh, sedangkan pengelola SMP IT 'AlQalam' lebih fokus mengelola dana Bos.

\section{Kekhasan SIT dalam JSIT}

Perbedaan Sekolah Umum dan Sekolah Islam Terpadu adalah Ke'Khasannya', sejak kemunculan sekolah Islam terpadu pada tahun 1992 ingin mewujudkan model sekolah yang mampu memadukan ilmu qauli dan qauni menjadi satu kesatuan dalam pembelajaran sehingga diharapkan melalui sekolah ini terlahir para peserta didik yang berkualitas, baik secara akademik maupun mental spiritual.

Selanjutnya dalam buku kekhasan Sekolah Islam Terpadu Misi dan tujuan utama pendirian SIT adalah mewujudkan sekolah yang secara efektif mengembangkan proses pendidikan yang dapat menumbuhkembangkan potensi fitrah anak didik menuju visi pembentukan generasi yang 'taqwa' dan berkarakter pemimpin. Sedangkan misi pendidikan SIT adalah: (1) Menuntaskan sasaran pembelajaran yang dicanangkan pemerintah dalam konteks kurikulum nasional; (2) Mengajarkan kemampuan membaca Al Quran dengan standar tahsin dan tartil (membaca sesuai aturan hukum tajwid), dan kemampuan menghafal Al Quran (tahfizhul Qur'an) dengan standar minimal dua juz setiap tingkatan satuan pendidikan; (3) Memperkuat pembelajaran agama Islam, dengan memperkaya konten konten kurikulum yang mengarah pada pemahaman dasar akan ajaran Islam dan fikrah, mauqif dan suluk Islamiyah;

Membina
karakter/Muwashofat kepada peserta didik secara bertahap menuju terbentuknya generasi pemimpin yang cerdas dan taqwa.

Sedangkan tujuan pendidikan SIT adalah membentuk 10 karakter utama kepada seluruh peserta didik, yaitu: (1) Salimul Aqidah; (2) Sohihul Ibadah; (3) Matinul Khuluq; (4) Qadirun 'alal Kasbi; (5) Mutsaqoful Fikri; (6 )Qawiyul-Jismi; (7) Mujahadah li Nafsihi; (8) Munazhom fi Syu'nihi; (9) Harisun 'alal waqti; (1) Nafi'un Ghorihi.

Membaca visi, musi dan tujuan dalam membentuk karakter peserta didik pada SIT cukup baik, bahkan sangat ideal untuk seorang anak yang masih melakoni pendidikan ditingkat dasar dan menengah, namun ada beberapa masukan yang penting untuk dipertimbangkan, pertama pendidikan harus memperhitungkan psikologi perkembangan anak, tidak boleh disamakan antara anak yang masih sekolah ditingkat SD dengan anak yang sudah beranjak remaja SMP dan SMA, hal ini akan sulit mencapai tujuan SIT secara optimal, kedua sebagai lembaga pendidikan yang berada di bumi Indonesia, tidak elok rasanya jika peserta didik juga tidak ajarkan tentang kearifan lokal, tradisi dan budaya yang ada di Indonesia perlu diperkenalkan, peserta didik harus menyadari bahwa Islam itu Rahmatan lilalamin, dalam tujuan membentuk karakter peserta didik, seolah anak terlalu dini untuk dipaksakan menjadi seorang 'pemimpin', termasuk tujuan pendirian SIT tidak terlepas dari tujuan pendidikan nasional sebagaimana yang diatur dalam UU sistem pendidikan nasional. Ketiga kesadaran berbangsa dan bernegara 
serta cinta pada tanah air juga harus ditanamkan pada peserta didik, janganlah membentuk sikap dan perilaku peserta didik yang bersekolah di SIT menjadi anak-anak 'eksklusif' dengan tuntutan yang terlalu tinggi. coba bandingkan 18 karakter yang dibuat oleh pemerintah dengan 10 karakter di atas yang ingin dibangun oleh SIT?

Pendidikan Karakter oleh Badan Litbang dan Pengembangan pusat Kurikulum Kemendiknas RI menyusun delapan belas karakter pendidikan budaya karakter bangsa. Delapanbelas pendidikan karakter (Kemendiknas, Balitbang Pusat Kurikulum dan Perbukuan 2011:8).

Perbandingan tuntutan harapan karakter SIT (sepuluh karakter) dengan yang dirancang oleh pemerintah (18 karakter) adalah target yang ingin dicapai oleh pemerintah pada level pendidikan dasar dan menengah tidak terlalu berat/tinggi (realistis), disesuaikan dengan perkembangan peserta dididk.

Perlu juga diketahui bahwa tidak semua sekolah Islam yang menggunakan kata 'Terpadu' tergabung dalam Jaringan Sekolah Islam Terpadu (JSIT) secara nasional, artinya di Indonesia ada juga Sekolah Islam Terpadu yang pengelolaannya secara independen dan tidak berafiliasi dengan JSIT.

Sekolah Islam Terpadu yang digolongkan menjadi 3 type di atas, hanya diistilahkan oleh penulis, hal ini melihat hubungan jaringan SIT dengan JSIT di Indonesia. Biasanya beberapa sekolah yang lebih dahulu menggunakan label "Islam Terpadu" kemudian sekolah tersebut telah berkembang dan membuka cabang diberbagai Provinsi di Indonesia biasanya hanya berkoordinasi saja dengan JSIT tanpa terikat sebagai anggota JSIT secara penuh, sedangkan sekolah yang juga berlabel "Islam Terpadu" secara independen tanpa terikat sebagai JSIT juga tidak dilarang menggunakan nama "Islam Terpadu”. Sementara SIT yang menjadi anggota JSIT sangat terikat dan harus mengikuti aturan-aturan yang ditetapkan oleh Pengurus Jaringan Sekolah Islam Terpadu.

Adapun kelebihan dari SIT yang masuk menjadi anggota JSIT, diantaranya sekolah mendapatkan bimbingan dan arahan tentang pengelolaan kualitas dari pengurus JSIT, mereka dapat belajar dan menimba pengalaman dari beberapa SIT di Indonesia yang masuk sebagai anggota JSIT.

Sedangkan kelemahan dari SIT yang masuk menjadi JSIT diantaranya karena keterikatan kekhasan kurikulum yang dikembangkan oleh JSIT membuat SIT di beberapa daerah kurang berinovasi, mereka terpaku dengan standar-standar yang telah dibakukan oleh JSIT, selain itu ideologi keberagamaan dimasing-masing daerah tentu berbeda jika melihat kondisi sosial kemasyarakatannya, sementara acuan yang ditetapkan oleh JSIT dalam standar ke-khasan SIT kurang fleksibel.

Hubungan SIT dengan JSIT sebaiknya hanya bersifat koordinatif tanpa terikat secara administrasi maupun substantif, mengapa demikian, ada beberapa pertimbangan menurut analisa penulis, walaupun ini perlu penelitian lebih lanjut, persoalan 
keberlanjutan dan koordinasi SIT dengan pemerintah pusat maupun daerah perlu ditingkatkan terutama Kemendiknasbud dan Kemenag, karena ini akan memberikan dampak positif terhadap perkembangan SIT selanjutnya, SIT dalam menerapkan kurikulum pendidikan Agama dan Kegamaan perlu duduk bersama dengan Kemenag sehingga cita-cita untuk mendidik dan membangun generasi masa depan dapat sesuai dengan UUD 1945, Pancasila serta searah dan sesuai dengan tujuan pendidikan nasional.

Visi JSIT adalah Menjadi pusat penggerak dan pemberdaya Sekolah Islam Terpadu di Indonesia menuju sekolah efektif dan bermutu.

Misi JSIT (1) Membangun jaringan efektif antar Sekolah Islam Terpadu di Indonesia; Meningkatkan efektifitas pengelolaan Sekolah Islam Terpadu di Indonesia; (3) Melakukan pemberdayaan pendidik dan tenaga kependidikan; (4) Melakukan pengembangan kurikulum Sekolah Islam Terpadu di Indonesia; (5) Melakukan aksi dan advokasi bidang pendidikan; (6) Menjalin kemitraan strategis dengan institusi nasional dan internasional; (7) Menggalang sumber-sumber pembiayaan pendidikan.

Tujuan JSIT (1) Terciptanya jaringan kerjasama antara peneliti, pengembang, pemerhati, penyelenggara, dan pengelola pendidikan atau sekolah yang menjadi anggota JSIT INDONESIA; (2) Meningkatnya kompetensi dan profesionalitas pendidik dan tenaga kependidikan JSIT INDONESIA; (3) Berlangsungnya proses perbaikan dan pengembangan Kurikulum
Sekolah Islam Terpadu; (4) Terjalinnya kemitraan strategis dengan instansi/institusi nasional maupun internasional.

Pada tahun 2010, JSIT Indonesia sebagai induk pemberdaya sekolah-sekolah Islam terpadu membuat standar mutu kekhasan sekolah Islam Terpadu, Standar mutu inilah yang dijadikan acuan secara nasional oleh SIT seluruh Indonesia yang tergabung dalam JSIT. Pada tahun 2013 panduan Standar Mutu Kekhasan SIT yang bergabung dalam JSIT direvisi kemudian diterbitkan pada tahun 2014 sebagai langkah awal melakukan akreditasi internal bagi SIT yang bergabung dengan JSIT, salah satunya adalah standar Pendidikan agama Islam yang menjadi fokus kajian ini.

Ada sisi baik dengan penambahan kualitas mutu kekhasan SIT terutama PAI baik secara monolitik maupun holistic termasuk hidden curriculum, karena menargetkan standar yang lebih tinggi dari pada sekolah umum lainnya, namun yang dikhawatirkan adalah sistem evaluasi lembaga pendidikan SIT secara nasional, BAN S/M tentu tidak memiliki kapasitas untuk menilai kualitas sekolah diluar standar yang ditetapkan oleh pemerintah, jika SIT memiliki organisasi tersendiri untuk mengevaluasi mutu pendidikannya mengapa pemerintah tidak dilibatkan dalam menilai kekhasannya, sebagai.

Beberapa SIT juga membuka kerjasama dengan negara tetangga, namun yang perlu diperhatikan adalah ideologi negara tersebut, jangan sampai kita hanya ingin mendapat keuntungan materi, sementara ideologi peserta didik 
sebagai warga negara Indonesia 'tergadaikan', inilah pentingnya pengelola sekolah melihat peratuan pemerintah nomor 32 tahun 2013, tentang Standar Nasional Mutu Pendidikan Indonesia serta Permendikas yang terkait dengan pendidikan secara nasional terutama Standar Isi dan Standar Proses.

"Realitasnya di SMP IT 'AlQalam' pada prinsipnya bukan hanya teori yang diutamakan, tapi praktek dalam ilmu keagamaan termasuk mengawasi langsung siswa dalam mempraktekkan apa yang menjadi perintah agama islam yang benar", Jelas Ibu Nurhafiah yang sudah tiga tahun bertugas di SMP tersebut.

"Kurikulum yang digunakan adalah kurikulum KTSP, pengembangan selanjutnya yang digunakan adalah kurukulum yang telah ditetapkan oleh jaringan sekolah Islam Terpadu", ungkap ibu Mami Guru PAI, kemudian Ibu Mami lulusan IAIN Kendari menjelaskan lebih lanjut bahwa "Konsep pendidikan terpadu bagi guru disyaratkan semua guru harus mengetahui sejarah Islam, jadi inilah yang juga menjadi prasyarat mengapa guru-guru dibutuhkan pengetahuan tambahan selain disiplin ilmu diluar pendidikan agama Islam”.

Semua pelajaran harus ditutup dengan hal yang berhubungan dengan akheratnya, jadi apapun yang dipelajari di SMP IT 'Al-Qalam' selalu ditutup dengan pelajaran yang berhubungan dengan nilai akhiratnya. Khusus pelajaran Pendidkan Agama Islam disesuaikan dengan kurikulum yang berlaku dan terstruktur, hal ini sama saja dengan sekolah umum yg mempelajari pendidikan agama,

Lebih lanjut Ibu Harfiah yang juga aktifis KAMMI saat mahasiswa menjelaskan "Dalam supervisi kepala sekolah melakukan hal-hal yang disesuaikan dengan asas supervisi”.

Rencana Program Pembelajaran (RPP) yang dibuat oleh seluruh guru SMP IT 'Al-Qalam' sangat spesifik sesuai dengan aturan yang ditetapkan oleh Jaringan Sekolah Islam Terpadu di Indonesia, sebagai gambaran kekhasan RPP yang dibua oleh SIT adalah tambahan indikator Spiritual yang tidak ditemukan pada RPP di sekolah umum

Untuk meningkatkan kualitas pembelajaran dan pengetahuan guru maka pada saat siswa libur, guruguru di SMP IT 'Al-Qalam' tidak libur, mereka diberikan pengayaan dalam evaluasi pembelajaran yngg telah dikerjakan oleh semua guru, termasuk pembuatan RPP, mereka diwajibkan untuk mempresentasikan rencana pembelajaran mereka didepan guruguru dan semua guru dapat memberikan tanggapan secara terbuka.

\section{Landasan Pengembangan Kurikulum PAI Di SMP-IT}

Keberhasilan sebuah lembaga pendidikan untuk mencapai tujuan pendidikan salah satunya adalah bagaimana mengemas kurikulumnya, pada prinsipnya kurikulum itu ada yang bersifat fungsional dan yang bersifat rencana, artinya kurikulum bukan hanya rencana tertulis bagi pengajaran tapi juga memberi pedoman yang mengatur lingkungan 
dan kegiatan yang berlangsung dalam kelas.

Menurut Hilda Taba (1962) dalam Majid (2014:3) perbedaan antara kurikulum dan pengajaran bukan terletak pada implementasinya, tetapi pada keluasan cakupannya.

Yang menjadi kritikan terhadap pola kurikulum PAI yang dikembangkan oleh JSIT adalah kurikulum yang sifatnya sempit terutama dalam pembelajaran PAI, dalam buku Standar Mutu Kekhasan JSIT langsung memberikan daftar penambahan kekhasan Sekolah Islam Terpadu, penulis melihat hal tersebut hanya bersifat pragmatis dan jangka pendek, padahal hakekat pengembangan kurikulum dalam sebuah sistem harusnya juga dijabarkan oleh JSIT, sehingga pengembangan kurikulum pada setiap satuan pendidikan tidak bersifat parsial.

Gambaran pengayaan kekhasan SIT menurut penulis justru bertentangan dengan hakekat pendirian SI yang menggunakan label "Terpadu" yakni Istilah "Terpadu" dalam SIT dimaksudkan sebagai penguat (taukid) dari Islam itu sendiri. Maksudnya adalah Islam yang utuh, menyeluruh, integral bukan parsial, syumuliah bukan juz'iyah.

Sebaiknya penjabaran standar mutu dalam memberikan penambahan kekhasan SIT, panduan pengembangan kurikulum lebih bersifat mengarahkan dengan pandangan yang lebih keindonesiaan, dengan berbagai alternatif wacana dan wawasan bukan sebuah doktrin kaku dengan harga mati! Hal ini berdampak pada eksklusifitas peserta didik dalam memandang PAI jika dibandingkan dengan lingkungan sosial masyarakatnya.

Ada hal yang menarik ketika penulis mewawancarai salah seorang orang tua peserta didik, saat ibunya makan berdiri, anak tersebut langsung menegurnya, betul apa yang dilakukan oleh anak tersebut menurut ajaran agama Islam, namun anak tersebut tidak sadar bahwa ada etika dan sopan santun yang perlu anak-anak ketahui terutama tata krama komunikasi dan perilaku antara anak dan orang tua, ada kata bijak menyatakan bahwa sesuatu yang baik namun cara penyampaiannya tidak baik penilaiannya tetap tidak baik.

Penambahan kekhasan SIT pada masing-masing satuan pendidikan, sebagaimana yang dituliskan dalam buku Standar Mutu kekhasan SIT, terkhusus pelajaran PAI kurang memperkenalkan pada peserta didik tentang rasa nasionalisme, hampir sebagian besar cerita dan contoh-contoh diungkapkan dalam penambahan kekhasan dibandingkan dengan Kompetensi Dasar menurut BSNP adalah Sejarah-Sejarah Islam yang nota bene awam dipahami oleh peserta didik pada satuan Pendidikan SMP bahkan SD, terkecuali para santri yang mengenyam pendidikan di pesantren, hal itu tidak salah, mengingat visi dan misi SIT, namun perlu juga disadari bahwa Islam di Indonesia juga memiliki sejarah tersendiri yang dapat diajarkan pada peserta didik.

Pada pengembangan kurikulum PAI pada SIT boleh saja berekspresi secara luas, terutama menggali Ajaran Islam secara Kaffah, dan itu 
sah-sah saja, namun perlu diingat bahwa sebagai warga negara yang baik tentu semua lembaga pendidikan wajib patuh pada aturan yang ditetapkan oleh pemerintah, khusus penyelenggaraan pendidikan, maka aturan yang dikeluarkan oleh Menteri Pendidikan Nasional wajib dipatuhi oleh lembaga pendidikan, terutama yang bergerak di sekolah swasta.

Dalam peraturan Menteri Pendidikan Nasional Republik Indonesia, Nomor 22 tahun 2006 Tentang Standar isi Untuk satuan pendidikan dasar dan menengah memberikan syarat untuk mengembangkan sebuah kurikulum,pada Bab II Point 2 dinyatakan: Kurikulum tingkat satuan pendidikan jenjang pendidikan dasar dan menengah dikembangkan oleh sekolah dan komite sekolah berpedoman pada standar kompetensi lulusan dan standar isi serta panduan penyusunan kurikulum yang dibuat oleh BSNP. Kurikulum dikembangkan berdasarkan prinsip-prinsip berikut: (1) Berpusat pada potensi, perkembangan, kebutuhan, dan kepentingan peserta didik dan lingkungannya; (2) Beragam dan terpadu; (3) Tanggap terhadap perkembangan ilmu pengetahuan, teknologi, dan seni; (4) Relevan dengan kebutuhan kehidupan; (5) Menyeluruh dan berkesinambungan (6) Belajar sepanjang hayat; (7) Seimbang antara kepentingan nasional dan kepentingan daerah. Ketujuh hal di atas, memberikan pedoman pada lembaga pendidikan jika ingin mengembangkan kurikulumnya
Keunggulan kurikulum Lokal dari SMP IT diantaranya adalah dengan memberikan pelajaran membaca Al-Quran, menghafal Hadits dan lain-lain yang berhubungan dengan Ajaran Islam hal ini cukup baik dan bermanfaat patut di apresiasi, namun dalam aturan pemerintah mengenai kurikulum muatan lokal yang diatur dalam Peraturan Menteri Pendidikan Nasional Republik Indonesia, Nomor 22 tahun 2006 Tentang Standar isi Kurikulum SMP/MTs memuat 10 mata pelajaran, muatan lokal, dan pengembangan diri.

Memadukan seluruh Pendidikan Agama Islam terhadap semua mata pelajaran di SMP IT adalah sesuatu yang baik, sehingga anak-anak sadar akan nilai Ajaran Islam dihubungkan dengan pelajaran di luar PAI, persoalannya adalah bagaimana Kapasitas dan kapabilitas pendidik (guru) yang mengajarkan Ilmu Agama Islam?

Sebagaimana yang dituliskan oleh Majid (2014:55-56) Struktur kuriulum SMP/MTs menggambarkan konseptualisasi konten kurikulum dalam bentuk mata pelajaran, posisi konten/mata pelajaran dalam kurikulum, distribusi konten/mata pelajaran dalam semester atau tahun. Struktur kurikulum merupakan aplikasi konsep pengorganisasian konten dalam sistem belajar dan pengorganisasian beban belajar dalam sistem pembelajaran.

$$
\text { Untuk mengembangkan }
$$
kurikulum maka minimal ada enam yang dijadikan landasan yakni: (1) Bagaimana menetapkan tujuan dan filosofi dari kurikulum yang dikembangkan; (2) Bagaimana pengaruh kurikulum yang 
dikembangkan terhadap sosial, budaya dan agama di masyarakat; (3) Bagaimana landasan yang dipakai pengaruhnya terhadap perkembangan karakterisitik peserta didik; (4) Kurikulum yang dikembangkan juga dilihat dampaknya terhadap lingkungan baik secara internal di sekolah juga eksternalnya di masyarakat; (5) Kurikulum yang dikembangkan juga harus memperhatikan kebutuhan pembanguna secara Nasional dan (6) Pengaruhnya terhadap perkembangan pengetahuan dan teknologi.

Pertama Kajian filosofi kurikulum SIT pada Pendidikan Agama Islam.

Filsafat pendidikan menjadi landasan untuk merancang tujuan pendidikan, prinsip-prinsip pembelajaran, serta perangkat pengalaman belajar yang bersifat mendidik, untuk itu filsafat pendidikan harus dirumuskan berdasarkan kriteria yang besifat umum dan obyektif. Hopkin dalam bukunya Interaction The Democratic Process, mengemukakan kriteria, antara lain: (1) Kejelasan, filsafat/keyakinan harus jelas dan tidak boleh meragukan; (2) Konsisten dengan kenyataan berdasarkan penyelidikan yang akurat; (3) Konsisten dengan pengalaman yang disesuaikan dengan kehidupan individu. (Hamalik, 2013:20)

Dari pandangan di atas, menurut pengamatan penulis, pada point pertama (1), sekolah Islam Terpadu telah memenuhi kriteria tersebut, namun pada point (2) dan (3), masih perlu di perdalam serta penyesuaian secara obyektif, karena ke-khasan SIT yang selama ini menjadi 'andalan' dan 'kelebihannya' masih menutup diri pada keunikan individu peserta didik, termasuk kenyataan lingkungan individu peserta didik apakah sudah diselidiki secara akurat.

Para pengelola SIT juga perlu menyimak Seperti yang dikemukan oleh Muhaimin (2012:vi) dalam mengembangkan pendidikan Islam perlu mendudukkan pemikiran dan pengembangan pendidikan yang dilakukan para ulama terdahulu sebagai pengalaman mereka dan dalam konteks ruang dan zamannya, untuk selanjutnya perlu diverifikasi, agar ditemukan relevansinya dengan konsteks sekarang dan yang akan datang. Hal-hal yang dipandang relevan akan dilestarikan, sebaliknya yang kurang relevan akan dicarikan alternatif lainnya dalam konsteks pendidikan muslim kontemporer.

GBPP (Garis-Garis Besar Program Pengajaran) adalah ikhtisar dari keseluruhan program pengajaran yang terdiri dari tujuan-tujuan kurikuler, Tujuan Instruksional dengan ruang lingkup bahan-bahan pengajaran yang disusun secara berurutan dan disusun menurut jangka waktu tertentu (semester atau catur wulan), (Suryosubroto, 2010:39)

Jika dihubungkan dengan pendidikan agama Islam dalam GBPP PAI tahun 1994, secara umum bertujuan "meningkatkan keimanan, pemahaman, penghayatan dan pengalaman peserta didik tentang agama Islam, sehingga menjadi manusia muslim yang beriman dan bertakwa kepada Allah Swt serta berakhlak mulia dalam kehidupan pribadi, bermasyarakat, berbangsa dan benegara. 
Selanjutnya juga dalam GBPP Mata pelajaran PAI kurikulum 1994 dijelaskan bahwa pada jenjang Pendidikan Menengah, kemampuankemampuan dasar yang diharapkan dari lulusannya dengan landasan iman yang benar, peserta didik: (1) Taat beribadah, mampu berzikir dan berdoa serta mampu menjadi imam; (2) Mampu membaca Al quran dan menulisnya dengan benar;

Memiliki kepribadian muslim (berakhlak mulia); (4) Memahami, menghayati dan mengambil manfaat sejarah dan perkembangan agama Islam; (5) Mampu menerapkan prinsip-prinsip muamalah dan Syariah Islam dengan baik dalam kehidupan bermasyarakat, berbangsa dan bernegara yang berdasarkan Pancasila dan UUD 1945.

Kedua Kurikulum PAI di SIT Pengaruhnya terhadap sosial budaya yang berlaku dalam masyarakat.

Pengaruh sosial budaya seharusnya menjadi perhatian dari pengelola SMPIT Al-Qalam, kota Kendari, secara statistik beragam suku dan budaya masyarakatnya, untuk itu hal ini harus menjadi perhatian, tradisi-tradisi yang lahir dalam lingkungan peserta didik juga harus diperkenalkan, ada suku Bajo, Bugis makassar, Buton dan orang Tolaki dengan berbagai kearifan lookalnya juga harus diperhatikan oleh pengelola SMPIT Al-Qalam. Peserta didik harus diperkenalkan dengan kearifan lokal lingkungannya. Secara Kekhasan kurikulum yang dibuat sudah baik, bahkan patut untuk diapresiasi dengan mengajarkan pendidikan akhlak bagi peserta didik, namun pendidikan budaya setempat juga perlu digali sebagai bagian dari kekhasan SMPIT Al-Qalam.

Ketiga Kurikulum PAI di SIT Pengaruhnya terhadap perkembangan karakteristik peserta didik.

$$
\text { Secara psikologi }
$$

perkembangan anak, terutama yang menginjak remaja, sangat rentan dengan pencarian jati diri, dalam arti kelabilannya sangat fluktuatif, untuk itu kurikulum PAI kekhasan SMPIT Al-Qalam perlu menelaah secara mendalam tentang karakteristik peserta didik terutama di usia SMP, pola kurikulum yang hanya memperhatikan perilaku secara visual harus diseimbangkan dengan 'sikap tanpa kontrol' yang terkadang dilampiaskan di rumah bukan di sekolah, sebagaimana yang diungkapkan oleh salah satu orang tua peserta didik, yang terkadang melupakan 'etika tradisi' yang berlaku umum di keluraga

Keempat Kurikulum PAI di SIT pengaruhnya terhadap lingkungan.

Sebagaimana dikemukakan sebelumnya bahwa lingkungan menjadi penentu dalam kesuksesan mengembangkan kurikulum di sekolah, lingkungan ini bukan saja yang dibuat oleh sekolah sebagai budaya sekolah SMPIT Al-Qalam, tapi juga lingkungan masyarakat dan lingkungan keluarga peserta didik harus diperhatikan secara seksama, untuk itu perlu kearifan pengelola SMP IT Al-Qalam mengembangkan Kurikulum PAI, terutam yang bersifat Holistik (hidden curriculum)

Kelima Kurikulum SIT Kebutuhan Pembangunan Nasional

Dalam tujuan pembangunan nasional, mencerdaskan pengetahauan, sikap dan perilaku peserta didik merupakan hal yang 
mutlak, selain itu nilai-nilai nasionalisme sebagai warga negara yang baik, juga perlu menjadi perhatian ketika SMPIT Al-Qalam mengembangkan kurikulumnya. Kekhasan PAI yang dibuat oleh JSIT sebagai lembaga koordinir untuk Sekolah Islam Terpadu di Indonesia dapat lebih disesuaikan dengan citacita bangsa Indonesia, pengenalan terhadap sejarah Islam di Indonesia juga menjadikan mereka bangga sebagai Bangsa Indonesia.

Keenam Kurikulum PAI SIT Pengaruhnya terhadap perkembangan pengetahuan dan teknologi.

Pada pengembangan kurikulum kekhasan SMPIT Al-Qalam sudah optimal, walaupun untuk pemenuhan sarana dan prasaran yang dimiliki masih perlu ditingkatkan, terutama media pembelajaran yang digunakan oleh pendidik dalam melakukan proses pembelajaran.

\section{Komponen Pengembangan Kurikulum PAI di SMP-IT}

Peraturan Menteri Pendidikan Nasional Republik Indonesia Nomor 41 Tahun 2007 Tentang Standar Proses Untuk Satuan Pendidikan Dasar Dan Menengah khususnya pendidikan Agama dan Akhlak Mulia SMP/MTs/SMPLB*/Paket B dituliskan: (1) Mengamalkan ajaran agama yang dianut sesuai dengan tahap perkembangan remaja; (2) Menerapkan nilai-nilai kejujuran dan keadilan; (3) Memahami keberagaman agama, budaya, suku, ras, dan golongan sosial ekonomi; (4) Berkomunikasi dan berinteraksi secara efektif dan santun yang mencerminkan harkat dan martabatnya sebagai makhluk Tuhan; (5) Menerapkan hidup bersih, sehat, bugar, aman, dan memanfaatkan waktu luang sesuai dengan tuntunan agamanya; (6) Memanfaatkan lingkungan sebagai makhluk ciptaan Tuhan secara bertanggung jawab; (7) Menghargai perbedaan pendapat dalam menjalankan ajaran agama .

\section{Materi Pendidikan Agama dan Akhlak Mulia;}

Perlu juga diketahui bahwa materi pendidikan Agama dan Akhlak Mulia, yang diajarkan di SMPIT Al-Qalam, seperti telah dijelaskan sebelumnya, nilai-nilai Ajaran Islam, di integrasikan pada semua mata pelajaran, bahkan Faktanya RPP yang dibuat stukturnya berbeda pada umumnya, perbedaan yang mendasar pada (1) Indikator, ada tambahan aspek Spiritual, pada semua mata pelajaran yang diajarkan, jadi bukan saja pada Pelajaran API; (2) Pada kegiatan inti (60 menit) pembelajaran, RPP yang dibuat langkahnya tertulis TERPADU, yang merupakan terjemahan dari Telaah, Eksplorasi, Rumuskan, Presentasikan, Aplikasikan, Duniawi, Ukhrawi, jika diperhatikan awalan dari masingmasing langkah pembelajaran maka akan terbaca TERPADU.

Yang perlu diperhatikan bahwa dalam komponen mengembangkan kurikulum, aspek-aspek tertentu dalam materi diantaranya: (1) teori; (2) Konsep; (3) Generalisasi; (4) Prinsip; (5) Prosedur; (6) Fakta; (7) Istilah; (8) Contoh dan Ilustrasi; (9) Defenisi; (10 ) Preposisi. Kesepuluh hal ini menurut Hamalik (2013:2526) menjadi aspek yang penying dalam menyusun kurikulum dari segi materi. 


\section{1) Metode Pendidikan Agama dan Akhlak Mulia; \\ Metode yang digunakan dalam} pembelajaran PAI sudah baik, bahkan menurut penulis kreatifitas dan inovasi metode yang digunakan patut diapresiasi, saat penulis melakukan observasi, Peserta didik mengikuti pelajaran PAI sangat menyenangkan karena saling berdiskusi.

Pada umumnya metode atau strategi dalam pembelajaran menempati fungsi yang penting dalam kurikulum, ada tiga alternatif pendekatan yang digunkan yakni: (1) Pendekatan yang berpusat pada mata pelajaran; (2) Pendekatan berpusat pada peserta didik dan (3) Pendekatan yang berpusat pada kehidupan masyarakat.

\section{2) Organisasi Pendidikan Agama dan Akhlak Mulia}

Pada organisasi kurikulum memang terdiri dari beberapa bentuk, menurut Hamalik (2013:27-28) ada lima ciri-ciri organisasi kurikulum yakni: (1) Mata pejaran terpisahpisah (isolated subjects); (2) Mata Ajaran-Mata Ajaran berkorelasi (Correlatied); (3) Bidang Studi (broadfield); (4) Program yang berpusat pada anak (Childrencentre Program); (5) Core program; (6) Electic program. Pada SMP IT AlQalam pengorganisasi kurikulum menggunakan Core Program.

3) Sistem evaluasi Pendidikan Agama dan Akhlak Mulia

Menarik untuk diketahui oleh masyarakat tentang sistem evaluasi yang diterapkan di SMP IT AlQalam, bahwa nilai yang diberikan pada peserta didik, bukan saja terbatas dari pengetahuan peserta didik, tapi sikap dan tingkah laku peserta didik juga menjadi bagian dari penilaian.

\section{Prinsip Pengembangan Kurikulum PAI di SMP-IT}

1) Relevansi

\section{Kurikulum PAI di SIT;}

Sebagai lembaga pendidikan prinsip pengembangan kurikulum harus disesuaikan dengan tujuan pendidikan nasional. Ada dua macam relevansi, yaitu relevansi internal dan relevansi eksternal. Relevansi internal adalah bahwa setiap kurikulum harus memiliki keserasian antara komponen-komponennya, yaitu keserasian antara tujuan yang ingin dicapai, isi, materi atau pengalaman belajar yang harus dimiliki peserta didik, strategi atau metode yang digunakan serta alat penilaian untuk melihat ketercapaian tujuan. (Rohman, 2012:170)

Pendapat rohman di atas pada prinsipnya juga sudah dijalankan oleh pengelola SMPIT, namun yang perlu diperjelas adalah pola keterpaduan kurikulum pendidikan umum dan pendidikan agama Islam, keserasian yang dimaksudkan juga harus memenuhi ketercapaian relevansi secara eksternal.

\section{2) Efektifitas dan Efisiensi Kurikulum PAI di SIT;}

Penerapan kurikulum kekhasan yang dikembangkan oleh SIT, akan menimbulkan biaya yang besar jika ingin menerapkan kekhasan secara menyeluruh, untuk itu ada beberapa pertimbangan jika SMPIT Al-Qalam konsep JSIT harus dilaksanakan sepenuhnya, konsekuensinya pembiayaan akan besar, termasuk penyediaan SDM yang memiliki kualifikasi Pendidikan Agama Islam. 
3) Fleksibilitas (keluwesan) Kurikulum PAI di SIT;

Perlu keluwesan dalam menyusun kurikulum di SIT, sehingga peserta didik dan pendidiknya dapat menyesuaikan diri secara cepat, karena kurikulum kekhasan yang dirancang oleh JSIT diIndonesia memerlukan penyesuaian secara menyeluruh, baik, materi, metode maupun kualifikasi pendidiknya.

\section{4) Tingkat Kontinuitasnya (Prinsip berkesinambungan) Kurikulum PAI di SIT; \\ Substansu kurikulum harus} mencakup keseluruhan dimensi kompetensi, bidang kajian ilmu dan mata pelajaran, pengelola SMPIT AlQalam juga harus memperhatian kesinambungan lulusannya untuk jejang berikutnya yakni SMA/MA.

\section{5) Keseimbangan Kurikulum PAI di SIT;}

Kurikulum SMPIT Al-Qalam harus menyeimbangkan antara kurikulum untuk kepentingan nasional dan kepentingan Jaringan sekolah Islam Teradu secara organisasi, ini perlu diperhatikan oleh pengelola SMPIT Al-Qalam, Kepentingan nasional dan kepentingan SIT sebagai lembaga pendidikan dibawah koordinasi JSIT harus saling mengisi dan memberdayakan sejalan dengan motto 'Bhinneka Tunggal Ika' dalam kerangka Negara Kesatuan Republik Indonesia.

\section{6) Mutu Kurikulum PAI di SIT.}

Penjaminan mutu kekhasan kurikulum di SMPIT secara internal dapat dijaga, karena SMPIT Al-
Qalam tergabung dalam JSIT da nada tim khusus yang menjamin dan menjaga mutu kurikulum kekhasannya, hanya saja sebagai SMP umum pertimbangan Diknas untuk pelajaran umum dan Kemenag dalam pendidikan agama Islam juga harus menjadi pertimbangan pengelola SMPIT.

\section{7) Kompetensi dan Kualifikasi SDM dalam menerapkan kurikulum kekhasan SMP-IT \\ Pembelajaran Pendidikan Aama} Islam di SMPIT Al-Qalam diajarkan oleh seorang guru PAI yang memang memiliki latarbelakang pendidikan Agama Islam dari IAIN Kendari berarti dari segi kompetensi dan kualifikasi Pendidikan secara administrasi sudah memenuhi syarat, hanya konsep kekhasan dengan memadukan pendidikan Agama dengan Ilmu Umum masih perlu di evaluasi, terutama pendidik yang memberikan pelajaran tentang Ilmu Agama Islam..

\section{PENUTUP \\ Kesimpulan}

1. Landasan dalam Pengembangan Kurikulum PAI di SMPIT lebih berorientasi pada sistem yang dibangun oleh JSIT, sehingga perlu mereduksi peraturan yang ditetapkan oleh pemerintah agar sesuai dengan tujuan pendidikan nasional.

2. Komponen yang di gunakan untuk mengembangkan kurikulum PAI di SMPIT, dari segi materi seharusnya memperhatikan budaya dan lingkungan masyarakatnya, tentu ada nilai tradisi di 
masyarakat yang perlu di adopsi dalam komponen kurikulum kekhasan yang dikembangkan oleh SMPI Al-Qalam, sehingga dapat berjalan sesuai dengan harapan

3. Prinsip-prinsip pengembangan kurikulum PAI di SMP-IT, yang harus menjadi perhatian adalah relevansi dan penjaminan mutu yang melibatkan stakeholder, bukan hanya berorientasi hanya pada penjamin mutu yang dibentuk oleh JSIT.

4. Sumber Daya Manusia (SDM) untuk mengawal kekhasan Kurikulum PAI SMP-IT sudah berjalan sesuai dengan paduan yang diberikan oleh JSIT, hanya saja perlu peningkatan Kualifikasi akademiknya agar pelaksanaan kurikulum PAI sesuai dengan harapan baik dalam pembelajaran yang sifatnya holistic maupun terintegrasi dengan pelajaran umum.

\section{Rekomendasi}

1. Pengelola SMPIT Al-Qalam dalam mengembangkan dan menjalankan kurikulum PAI diharapkan dapat melibatkan dan berkoordinasi dengan Kementerian Agama, sehingga ada relevansi tujuan yang ingin dicapai oleh SMPIT Al-Qalam maupun pemerintah dalam mencapai tujuan pendidikan nasional

2. Kementerian Agama perlu terlibat dalam pengembangan kurikulum PAI di SIT secara umum sehingga pendidikan Agama Islam yang menjadi kekhasan SMPIT dapat lebih berkualitas tanpa meninggalkan identitas local, budaya dan nasionalisme Pendidik dan peserta didik di SIT.

3. Perlunya Peningkatan kualifikasi akademik pendidik yang mengajarkan nilai keIslaman, terutama guru umum yang mengajarkan PAI di SMPIT Al_Qalam

\section{DAFTAR PUSTAKA}

Abidin, Zaenal. 2009. Sekolah dasar islam terpadu Sebagai sekolah alternatif di surakarta (Pengkajian tentang Varian Visi, Misi, dan Model Kurikulum) Jurnal Penelitian Humaniora, Volume 10, No. 2, Agustus 2009: 166-179.

Ahmadi, dkk 2012. Mengembangkan Pendidikan Berbasis Keunggulan Lokal dalam KTSP. Prestasi Pustaka. Jakarta

Apriani, Rilla. 2015. Peran kepala sekolah dalam meningkatkan Efektivitas kerja guru di sekolah dasar Islam terpadu (sdit) nurul hadi samarinda. eJournal Administrasi Negara Volume 3, Nomor 2, 2015: 564-577

Arifin, Zuhairansyah. 2014. Dilema Pendidikan Islam Pada Sekolah Elite Muslim Antara Komersial Dan Marginalitas. Jurnal Potensia vol.13 Edisi 2 Juli - Desember 2014 Halaman 177-200. 
Budi Hadi. Makalah. Manajemen Pendidikan Islam Terpadu Dalam Membentuk Siswa Berakhlak Mulia Studi Kasus di SDIT Muhammadiyah AlKautsar Gumpang Kartasura Sukoharjo Tahun 2012-2013. Program Pascasarjana Universitas Muhammadiyah Surakarta Tahun 2013.

Darmin, Sudarwan. 2006. Agenda Pembaruan Sistem Pendidikan. Pustaka Pelajar. Yogyakarta.

Euis Sumaiyah. Makalah. Implementasi Konsep Pendidikan Islam Terpadu Di SMP Islam Terpadu PAPB Pedurungan Semarang. Fakultas Tarbiyah Institut Agama Islam Negeri Walisongo Semarang 2010.

Hadiyanto, 2004. Mencari Sosok Desentralisasi Manajemen Pendidikan di Indonesia. Rineka Cipta. Jakarta

Hamalik, Oemar. 2013. Kurikulum dan Pembelajaran. Bumi Aksara. Jakarta.

Latef, Suryawahyuni. 2011. Rekrutmen Tenaga Pendidik di Sekolah Menengah Pertama Islam Tepadu Al Azhar Jambi. Jurnal Innovatio. Volume X, No. 1, Januari-Juni 2011 Halaman 195-207.

Muhaimin, 2012. Paradigma Pendidikan Islam - Upaya Mengefektifkan Pendidikan Agama Islam di Sekolah. Remaja Rosdakarya. Bandung

Mulyasa, 2014. Pengembangan dan Implementasi Kurikulum
2013. Remaja Rosdakarya. Bandung.

Rabingatin,siti. 2015. Implementasi Kurikulum Jaringan Sekolah Islam Terpadu Di Sekolah Menengah Pertama Islam Terpadu, Jurnal Syamil. Volume 3 (1) 2015. Halaman 127-154.

Rahman, Muhammad. 2012. Kurikulum berkarakter (Refleksi dan Proposal Solusi terhadap KBK dan KTSP). Prestasi Pustaka. Jakarta.

Rohiat. 2010. Manajemen Sekolah: teori dasar dan Proaktik. Refika Aditama. Bandung.

Sagala, Syaiful. 2007. Manajemen Strategik Dalam Peningkatan Mutu Pendidikan. Alfabet. Bandung.

Soemanto. 2014. Edukasi. Jurnal Penelitian Pendidikan Agama dan Keagamaan. Volume 12. Nomor 2. Hal. 247-260.

Supar. 2014. Strategi pemasaran sekolah dasar islam terpadu nurul fikri tulungagung. Jurnal Humanity Volume 10, Nomor 1 September 2014 halaman $158-170$

Suprapto. 2014. Edukasi. Jurnal Penelitian Pendidikan Agama dan Keagamaan. Volume 12. Nomor 1. Hal. 27-41.

Suryasubroto, 2010. Manajemen Pendidikan di Sekolah. Rineka Cipta. Jakarta.

Suyatno, 2015. Sekolah Dasar Islam Terpadu Dalam Konsepsi Kelas Menengah Muslim Indonesia, Analisa Journal of 
Social Science and Religion

Volume 22 No. 01 June 2015

halaman 121-133

Suyatno. Makalah Penelitian.

Sekolah Islam Terpadu Dalam

Peta Sistem Pendidikan

Nasional. Prodi PGSD

Universitas Ahmad Dahlan

Yogyakarta.

Tilaar, H.A.R. 2006. Standarisasi Pendidikan Nasional suatu Tinjauan Kritis. Rineka Cipta. Jakarta. 